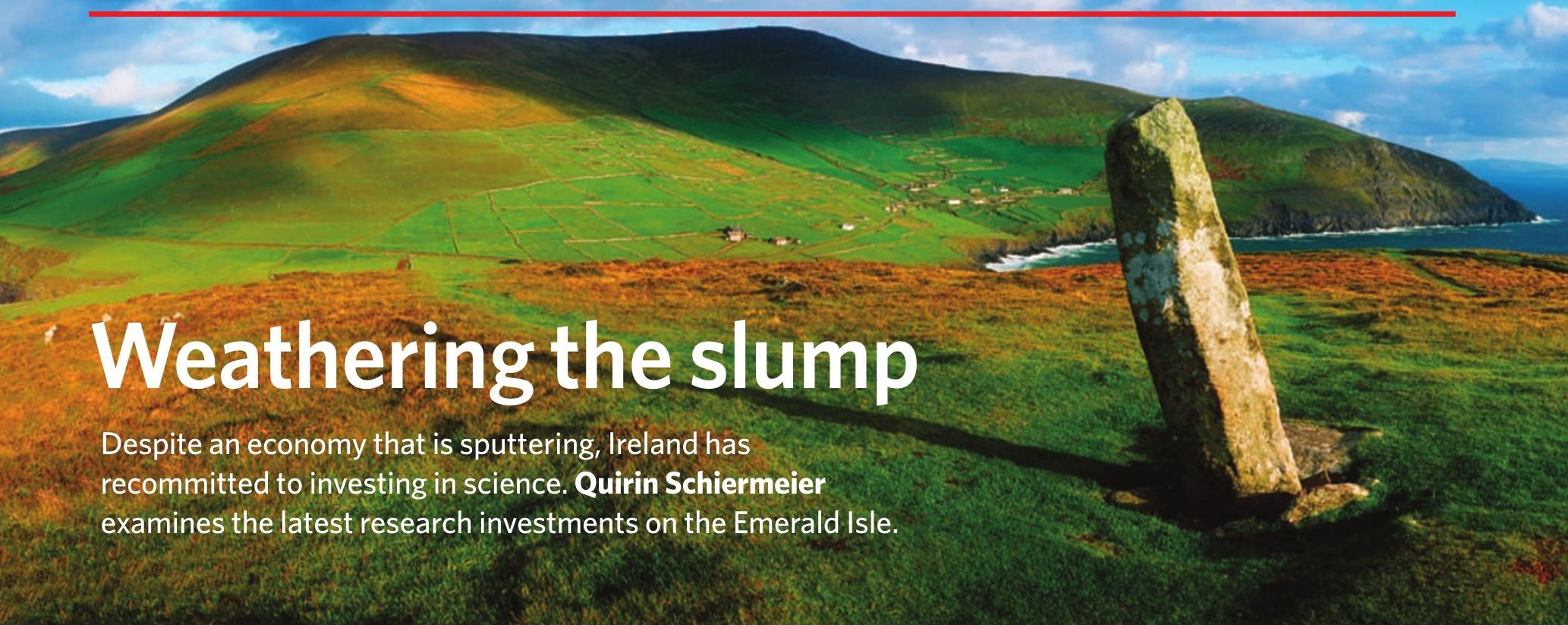

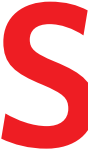

cientists in Ireland held their breath last autumn as the financial storm that started in Manhattan hit their high-revving economy, buffeting the housing and construction sectors. It was a relief when, after a few tense weeks, the government redoubled its support for science.

Renewed investment in science and development play a key part in Ireland's recovery plan. "That the government has not blinked, despite the dire economic situation, sends a very strong signal to the Irish research community," says Frank Gannon, director of Science Foundation Ireland (SFI), a government-funded grant-giving agency. Its creation in 2000 , with an influx of new funds, heralded the dawn of a new era for Irish science (see Nature 444, 396-397; 2006).

In December, as an economic downturn seemed likely, the Taoiseach (prime minister) Brian Cowen reaffirmed a previous commitment to invest some $€ 8.5$ billion (US $\$ 10.6$ billion) in science over the next six years. In its framework for sustainable economic revival, the government outlined 45 key actions from $\mathrm{a} € 500$-million venture fund to support research and development by early-stage companies, to fast-track visas for foreign researchers and their spouses - aimed at turning Ireland, with its population of 4.2 million, into an 'island of innovation'.

With cash in hand, and newly introduced peerreview standards to help ensure quality research, the SFI helped to start a remarkable upswing that attracted talent from abroad and kept Irish scientists in the country. Funding is available in three governmentestablished growth areas considered vital for Ireland's future: the life sciences and biotechnology, information and communication technologies, and sustainable energy and energy-efficient technologies. Its annual $€ 200$-million budget will continue to grow at the same rate, around $4 \%$, as in previous years. This, says Gannon, should be sufficient to keep up the healthy $25 \%$ success rate of applicants for individual SFI grants, including 'research frontiers' grants for more risky science, 'starting investigator' grants for early career scientists, and principal-investigator grants worth $€ 250,000$ per year on average.

The SFI's funding activities, through government agencies such as Enterprise Ireland and Industrial Development Agency Ireland, are part of a broader

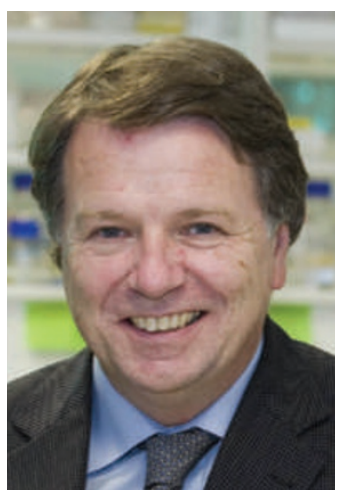

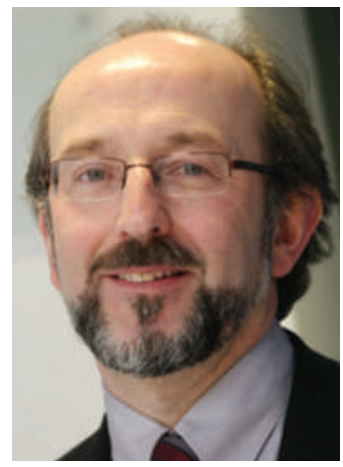

Fergus Shanahan and Brian MacCraith see the benefits of industry partnership. strategy aimed at transforming Ireland's manufacturing sector. Some $40 \%$ of SFI-funded investigators have active connections with industry. Overall, $90 \%$ of Ireland's public-science funding is earmarked for research with potential commercial applications in an attempt to maximize jobs and economic growth.

Despite these programmes, Ireland's research expenditure is still relatively modest. At around $1.4 \%$ of gross domestic product, research spending in the republic is considerably below the European Union (EU) average, and even slightly below that of China. But in terms of numbers of researchers, Ireland, with 5.7 researchers per thousand in the labour force, is now ranked slightly above the EU average (5.6), and is almost on par with Switzerland (5.8) and Britain (6.2), according to 2006 figures just released by the EU.

Small size has its virtues. "We're able to have a census of all groups we support," says Gannon. "That's a real advantage when it comes to coordinating our research efforts." All researchers applying for SFI grants must demonstrate how the project could have an economic impact. Applications for the flagship scheme, the SFI Centres for Science, Engineering and Technology (CSET), through which large academic-industrial partnerships can receive up to $€ 5$ million per year, undergo particularly thorough review. Centres are expected to focus on research with commercial potential and to deliver publications and patents.

Among the CSET beneficiaries is Fergus Shanahan, director of the Alimentary Pharmabiotic Centre at University College Cork, which is run in partnership with GlaxoSmithKline. He recently won a second round of funding. Over the next five years, the SFI will support the centre - one of nine ventures funded through the CSET programme - with an overall $€ 17.5$ million; an additional $€ 5$ million will come from industry. "It's a blessing in these times that the government has reconfirmed so determinedly its commitment to science," says Shanahan. "I do hope we can repay the trust over the next five years." He expects opportunities for geneticists, microbiologists, clinicians and others.

All 56 group leaders and young investigators who have moved through the centre since its creation five years ago are still in science, most of them in Ireland, and most of them have moved up the career ladder. Around one-half are now working for industry. The 


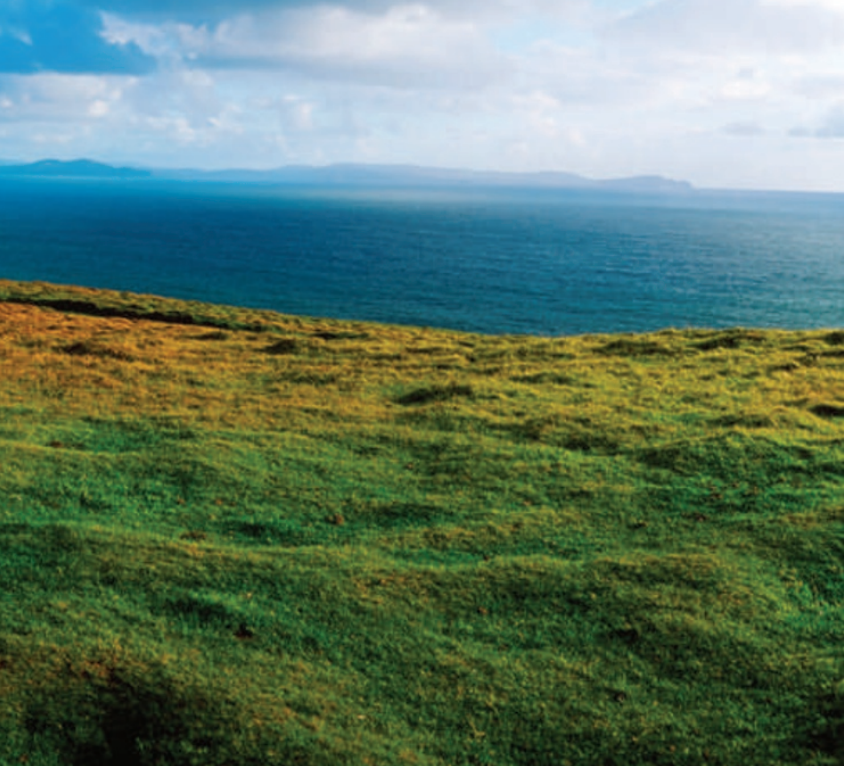

centre itself, says Ferguson, has become more international. The number of non-Irish natives among its 125 staff has doubled to $30 \%$ as more scientists from Europe, North America and Asia-Pacific have been recruited, suggesting that Ireland continues to be a draw. "Salary has long ceased to be a recruitment hindrance," says Shanahan.

\section{The hub of activity}

Dublin hosts much of the action. Last year, Ireland's first official nanoscience institute, the SFI-funded Centre for Research on Adaptive Nanostructures and Nanodevices, moved its 100 or so researchers into a stylish five-story building complete with an art gallery. The centre, is, among other things, developing nanoscale biosensors for virus detection.

Three new CSET centres opened their doors in Dublin last year. One was the Centre for Next Generation Localisation, led by Josef van Genabith of Dublin City University. Working with IBM and Microsoft, the centre is adapting computer software to different languages and regional cultures. And CLARITY, led by Barry Smith of University College Dublin, aims to improve sensor technology for wireless transmission of messages. Such sensors could be used to transmit large environmental data sets. Industrial partners include Ericsson, Vodafone and IBM.

Setting up a CSET centre, which typically employs $100-150$ scientists, requires at least $25 \%$ involvement from industry in the form of money, personnel or both. These partnerships have various arrangements. At the

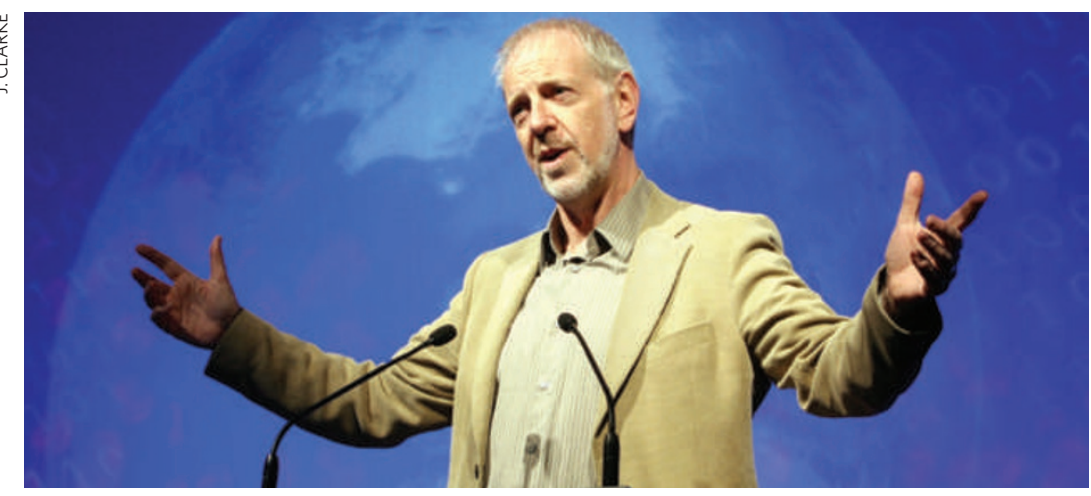

Size is important: Ireland's size allows Frank Gannon to better coordinate research.
Biomedical Diagnostics Institute at Dublin City University, for example, researchers from participating companies, including the biotech company Amic from Uppsala, Sweden, and medical technology company Becton Dickinson, headquartered in Franklin Lakes, New Jersey, are working with colleagues from academia. "This creates a very productive and

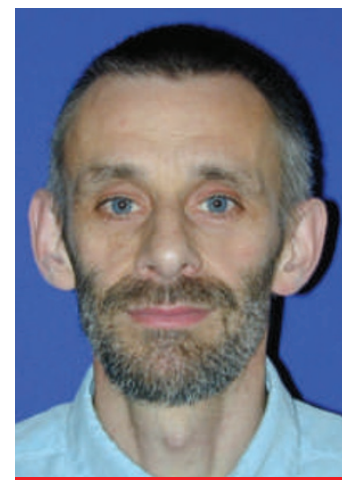

"If you have the

right company

and the right idea

there is still plenty

of seed money

available."

- Kingston Mills innovative work environment," says Brian MacCraith, an optical physicist who runs the centre, which was established in 2005 with a $€ 16.5$-million SFI grant.

Arranging industry participation can take time, because it requires agreements on funding, patents and royalties. So in 2007, the SFI created the Strategic Research Clusters programme to back commercially promising ideas, giving investigators more time to attract and cultivate industry partnerships. Twelve such clusters have been announced so far, each funded by up to $€ 1.5$ million per year over a five-year period, and focusing on topics ranging from solar energy conversion to dairy-cow fertility.

Kingston Mills, an experimental immunologist, leads one such cluster, the Immunology Research Centre at Trinity College Dublin. It is a $€ 10$-million, five-year research programme. Since funding started early last year, he has recruited one group leader, nine postdocs and five $\mathrm{PhD}$ students whose research focuses on the discovery and function of novel activators and inhibitors of innate immunity. Private partnerships with Opsona Therapeutics, a Dublin-based spin-off company for vaccine development that Mills started in 2004, and the pharmaceutical firm Schering-Plough contribute some $20 \%$ to the overall funding. "Raising funds has become more difficult," he says. "But if you have the right company and the right idea there is still plenty of seed money available."

Meanwhile, Enterprise Ireland has announced that it will invest $€ 20$ million in a new research centre for functional foods designed to provide health benefits beyond basic nutrition. And $\mathrm{a} € 150$-million Biosciences Institute is being built in a public-private partnership involving Trinity College Dublin. Its planned opening in 2011 should provide collaboration opportunities for $\mathrm{PhD}$ students.

Ireland's government is seeking to double the number of $\mathrm{PhD}$ students over the next five years. But a decline in core funding - money that the ministry of education gives to Ireland's seven research universities - could affect this, says Mills. These funds cover running costs, such as electricity, building repairs and salaries. Fixed university budgets are to be cut further, by approximately $7 \%$ this year. "Grant money keeps increasing while core funding is eroding," says Mills. "There's a disconnection."

To bridge the gap, some government officials and university rectors favour the re-introduction of undergraduate student fees, which were abolished more than a decade ago, to provide greater access to higher education. Irish students hate the idea, but its champions argue that free education is no longer justified when so many Irish families can now easily afford to pay for it.

More families, however, could feel the pinch as the economy continues to cool. But the Irish economy has acquired a serious affinity for science - an affinity that should provide ample research opportunities for students and scientists for the foreseeable future. 